梅田廎三郎○(福山大学・エ), Wen-Je1 Yang (ミシガン大), 塩野正顕, 谷口輝（福山大学大学院）

\title{
Characteristics of Vortices in Louver Fins
}

\author{
Shınzaburo UMEDA, Wen-Jeı YANG, Masaakı SHIONO and Akıra TANIGUCHI
}

\begin{abstract}
Research results pertınent to heat exchangers are avallable in existing literature and heat transfer text books However, it was short of sufficient flow visualizations in louver fins because of the difficulty in its flow visualization Flow visualization by means of the dye injection method and the laser Doppler velocimetry (LDV) was performed to disclose flow characteristics in louver fins Fin pitches $P_{f}$ and louver angles $\theta$ in louver fins were varied Flow patterns in each louver fins are visualized using the fluorescein dye illuminated a laser light sheet The LDV data were used to calculate Reynolds stress distributions and power spectrum distributions It is disclosed that vortices in cases of $\theta=15^{\circ}$ and $20^{\circ}$ for $P_{f}=100 \mathrm{~mm}$ exhibit a distinctive penodic characteristics, and the Strouhal number is uniquely related to the Reynolds number
\end{abstract}

Key words Louver fins, Dye injection method, LDV, Vortices

\section{1 まえがき}

コンパクト形熱交換器ては, 小型·軽量化と同時に伝 熱性能の向上か求められ, 高性能な伝熱面としてルーハ 一フィンをはしめとしたフィン型式が用いられている それらのルーハーフィン内の流れには強い三次元特性 かあらわれているが,これまでの研究では,ルーバーフ インまわりの流れの可視化が不十分で, 特に乱流一の遷 移領域付近の Re 数の大きい場合の流れの十分な解明に は至っていないと思われるこれには,ルーバーフィン なとの配列形状の複雑な物体まわりの流れの可視化の 困難さも関係していると思われる

昨年 ${ }^{1)}$ に続き, ルーバーフィンまわりの流れについて 住入トレーサ佉及び二次元レーザ流速計（LDV）を用 い,フィンピッチやルーバー角度を変化させた場合の可 視化実験を行った 特に, ルーバーフィンまわりに発生 する楇の構造及びその振動特性の解明を試みた

\section{2 実験方法}

実験装置の概要を図-1 (a) と (b) に示す 上流側水槽に $800 \mathrm{~mm}$ の管路長の助走区間, 縱・横 3 列のルーハーフィ ンを配置した $750 \mathrm{~mm}$ の管路長の試験区間及び流量調節 用の下流側区間のそれぞれの管路を接続した 管路幅 B は $600 \mathrm{~mm}$ となっているいすれれの管路も透過性のアクリ ル樹脂板で製作した 上流側水槽へッド Hu と下流端管 路の底にあけた穴の開閉の数を調節することによって 管路内の流量を変化させた またルーハー角度 $\theta$ を $10^{\circ}, 15^{\circ}$ 及び $20^{\circ}$ の 3 種類, フィンピッチ $\mathrm{P}_{\mathrm{f}}$ を 50
と $100 \mathrm{~mm}$ の 2 種類を選び, それらの違いによる流れの変 化を調へた 今回の実験の Type の分類を表ー1にまと めて示す なお, ルーバーフィン長 L は, 1 列目が $300 \mathrm{~mm}$ で， 2 列目と 3 列目は $200 \mathrm{~mm}$ となっている ルーバー長 $\mathrm{P}_{1}$ 及びフィンの厚さ $\mathrm{t}$ は，それぞれ 100 及ひ $5 \mathrm{~mm}$ となっ ている

このようなルーハーフィンに関する大きな実験装置 を製作し，蛍光染料を用いた注入トレーサ法によりルー ハーフィンまわりの流脈の可視化を行ったこの場合, 試験区間にアルコンレーザによるシート光を管路側面 から水平に照射し，管路上方に設置したカメラで水平断 面における统れの可視化撮影を行った その他に，2 列 目のルーバーフィンの中央断面 (以下では 2-C の記号を 用いる) や 3 列目の入口断面 (3-E) と図-1 (c) に示す 3 列 目の計測領域の最下流側断面 (3-6)のそれそれれ鉛直断 面に上方からシート光を照射し，下方に設置したカメラ からのそれらの流れの可視化も行った

その他に，LDVを用いてルーバーフィンまわりの流 速及びその変動の計側を行った 図-1(c)に示す 2 列目 の左側（流下方向に向かっての左側）領域及ひ 3 列目入 口付近の管路中央水深での水平断面に計側格子を設け たそれらの水平断面の計測以外に, I 及びIIIで鉛直 断面の計則格子上でも流速測定を行った さらに, 同図 の@印を示す 3 列目入口付近の点においても流速変動 を計側し, 得られた時系列データからその変動の振動解 析も行った

なお， 1 列目のフィン区閒での流入流速分布も調べ, それらから得られた平均流速 $\mathrm{U}_{0}$ を Re 数の代表流速に選 
んだ、代表長さには $\mathrm{P}_{\mathrm{f}}$ を選んだ、今回の $\mathrm{P}_{\mathrm{f}}$ には 50 と $100 \mathrm{~mm}$ の 2 種類の間隔のものを選んだので, Re 数を同じ にした場合には $\mathrm{U}_{0}$ が大きく異なっている，そのため流 れの比較にあたっては, $\mathrm{U}_{0}$ がほぼ同じ程度になるものを 選んだ.

\section{3. 実験結果}

\section{1 注入トレーサ法による流脈の可視化}

蛍光染料をルーバーフィンまわりに注入し,アルゴン レーザシート光を照射して流脈の可視化を行った. 管路 上方及び下方から撮影した結果の二例を図-2.1 と 2.2 に示す.

まず，図を省略しているフィンピッチが $50 \mathrm{~mm}$ でルー バー角度が $10^{\circ}$ の Type A-1 の場合には, ルーバーフィ ンの並びの変化が小さく,幅も狭いために流れの変化も 小さくなっていた. 図一 2.1 に示すルーバー角度を $15^{\circ}$ に広げた Type A-2 では, フィン入ロや曲がりの部分の

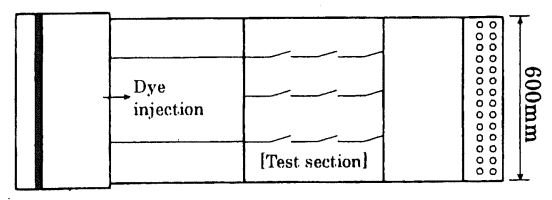

(a) Top view

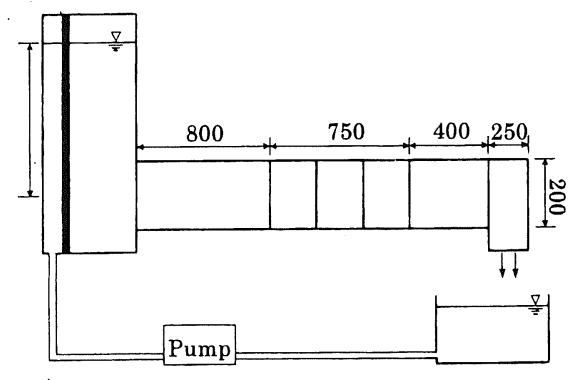

(b) Side view

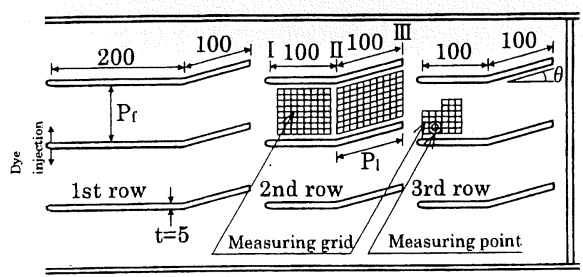

(c) Test section

Fig.1 A schematic of experimental setup and measuring grids

Table 1 Kinds of ducts with louver fins

\begin{tabular}{|c|c|c|c|c|c|c|}
\hline Type & A-1 & A-2 & A-3 & B-1 & B-2 & B-3 \\
\hline Angle of louver & $10^{\circ}$ & $15^{\circ}$ & $20^{\circ}$ & $10^{\circ}$ & $15^{\circ}$ & $20^{\circ}$ \\
\hline Fin pitch $: \mathrm{P}_{\mathrm{f}}$ & \multicolumn{3}{|c|}{$50 \mathrm{~mm}$} & \multicolumn{3}{|c|}{$100 \mathrm{~mm}$} \\
\hline Length of louver fin $: \mathrm{P}_{1}$ & \multicolumn{4}{|c|}{$100 \mathrm{~mm}$} \\
\hline Thickness of fin $: \mathrm{t}$ & \multicolumn{3}{|c|}{$5 \mathrm{~mm}$} \\
\hline Depth of duct $: \mathrm{d}$ & \multicolumn{3}{|c|}{$200 \mathrm{~mm}$} \\
\hline Width of duct $: \mathrm{B}$ & \multicolumn{3}{|c|}{$600 \mathrm{~mm}$} \\
\hline
\end{tabular}

影響を受け，渦の形成がみられるようになっている.(a) の上方からの写真には, 1 列目中央及び 2 列目の中央と 左側のそれぞれのルーバーフィンの位置を一点鎖線で 示している.また (b) と (c)の管路の下方からの写真には, 3 列目の中央と左側の位置を一点鎖線で示した。図 -2.1(a)では, 1 列目のフィンの入口の影響を受けて流 脈の変化があらわれ,フィンの曲がり部分では渦の形成 を想像することができるような流脈の変化が大きくあ らわれている. 2 列目のフィン区間では流脈がさらに変 化し，（b）に示すように 2 列目のルーバーフィン中央位 置に相当するフィンの曲がり部分では縦渦の形成がみ られる.その流脈の変化は, 2 列目のルーバー区間でも 促進され，(c)に示すように細長い縦渦の形成がみられ， しかもその広がりは管路水深方向の中央部付近の範囲 となっている.

次に，フィンピッチを $100 \mathrm{~mm}$ に広げた Type B でのル 一バー角度が $10^{\circ}$ のものは, Type A の場合と同様に流

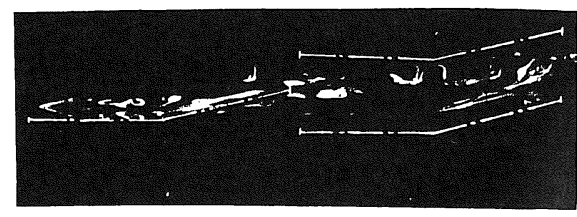

(a) Top view

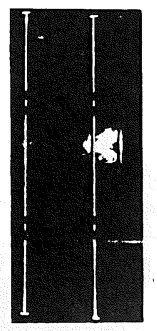

(c) Rear view (3-E section)

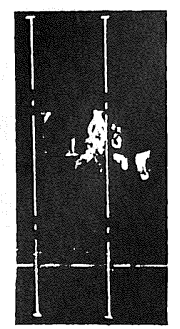

(d) Rear view (2-C section)
Fig.2.1 Flow patterns for Type $A-2$ and $\mathrm{Re}=1,200$

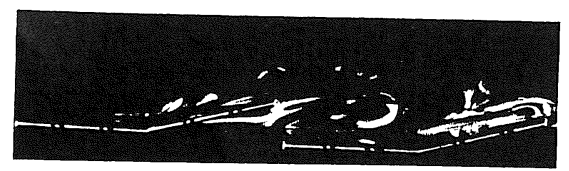

(a) Top view

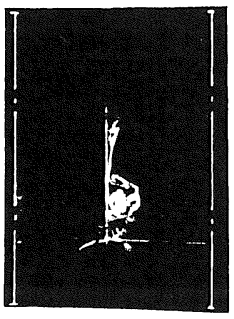

(b) Rear view (2-C section)

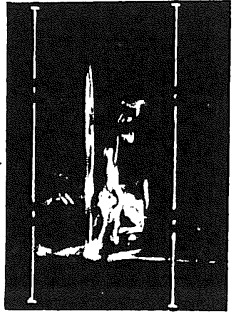

(c) Rear view (3-E section)

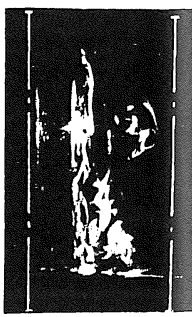

(d) Rear view (3-6 section
Fig.2.2 Flow patterns for Type B-2 $\mathrm{Re}=1,600$ 
脈の変化が小さかった，図-2.2 に示すルーバー角度が $15^{\circ}$ でRe 数が 1,600 の場合では，(a)図に示されるよう に 2 列目のフィン入口付近ではっきりと流脈の変化が あらわれ，渦の形成を想像することができる.（b)図で 示す 2 列目ルーバーフィン中央位置付近では, 流脈が上 下方向に広がり,さらに (c)や (d) に示す 3 列目のフィン に入った部分では左右にも広がり, はっきりとした縦渦 の形成がみられる，図を省略したルーバー角度を $20^{\circ}$ に広げた Type B-3 では, Type B-2 と同様に流脈の変化 が大きくあらわれ, 数個所にわたって旋回寸る縦渦がは っきりとみられる.

\section{2 平均レイノルズ応力分布}

2 列目及び 3 列目入口付近の流速及びその変動をL D Vによって計測した. 紙面の都合で流速変動による平均 レイノルズ応力分布についての結果のみを示す.

2 列目の I - III区間及び3列目のそれぞれの計測領域 での平均レイノルズ応力- $\overline{\mathrm{u}^{\prime} \mathrm{v}}, / \mathrm{U}_{0}^{2}$ の結果の一例を図 -3 に示す.（a)に示す 2 列目の結果では, 上流側から 下流側に向かう右側のルーバーフィン中央部前後の屈 曲部付近にレイノルズ応力の変化がはっきりとあらわ れている. 次の (b)に示す 3 列目入口付近の計測領域で のレイノルズ応力の変化については, 2 列目のレイノル ズ応力の值のスケールとは異なり,ルーバー背後とフィ ン側でのそれぞれの応力の変化が大きくあらわれてい る.

最後に, 3 列目入口付近の計測領域の鉛直断面での等 レイノルズ応力分布図の結果の一例を図ー4に示す. 流 下方向に向かって並べられたいずれの断面においても それぞれの断面の中央部付近に負のレイノルズ応力の 值があらわれ，それらのまわりは逆にほとんどが正のレ イノルズ応力の值となっている.また (b)と (d) での負の ピーク值については，(b)では上方に，(d)では下方に, それぞれ上下の異なった位置にあらわれている.

以上のような 2 列目及び 3 列目の入口付近の流速及び その変動結果から，2 列目の屈曲部であらわれた流れの 変化が 3 列目入口付近では上下及び左右方向に大きく 変化し，三次元的な流れへと発達していると思われる.

\section{3 流速変動のスペクトル解析}

ルーバー角度や Re 数の違いによってルーバーフィン まわりの流れが異なることから，LDVを用いて流速の 変動の時系列データを測定した. 図-1 (c)に示す@印で 示す 3 列目のルーバーフィン入口付近で流速変動を調 ベた. 得られた時系列データよりパワースペクトルを求 めた。

3 列目のルーバーフィン入口付近での測定点の結果 については，フィンピッチの狭い場合の Type A でのパ ワースペクトルは, ルーバー角度や Re 数によってその 形が異なっている. ルーバー角度が $10^{\circ}$ や $20^{\circ}$ の場合 には、いずれも卓越周波数があらわれるようなスペクト ルはほとんど見られなかった.それぞれの場合にはルー

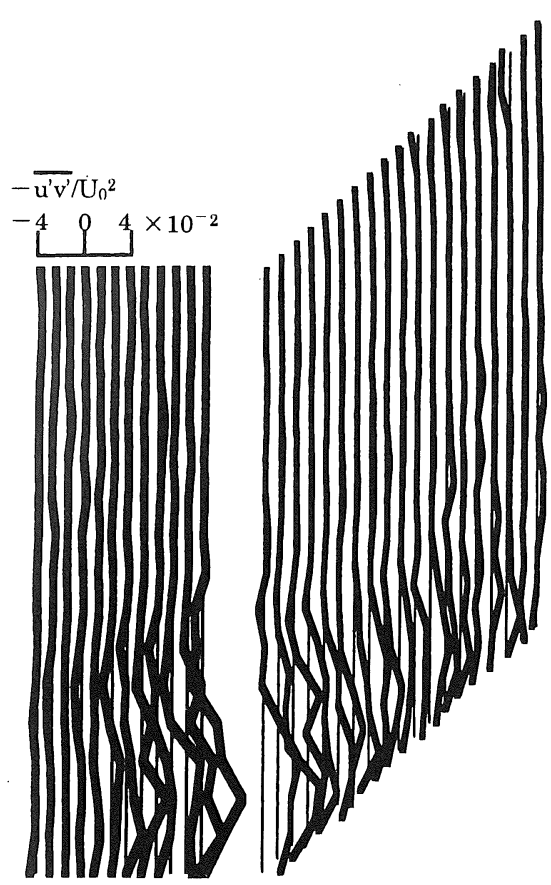

(a) Second row

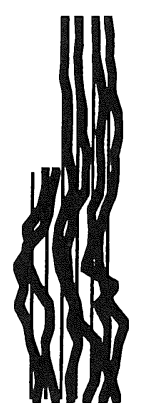

(b) Third row
Fig.3 Reynolds stress distributions on horizontal section at louver fins for Type $B-3$ and $R e=1,600$

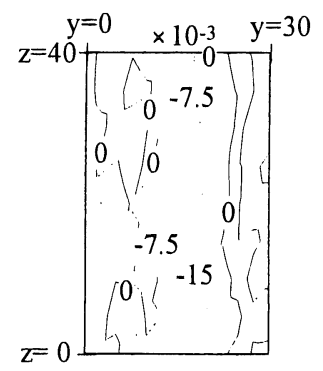

(a) $\mathrm{x}=0 \mathrm{~mm}$

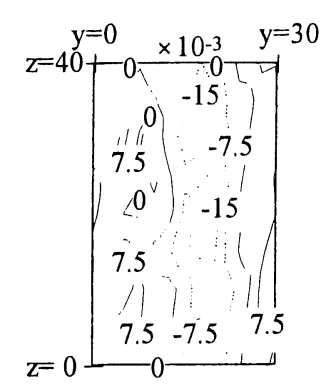

(b) $x=5 \mathrm{~mm}$

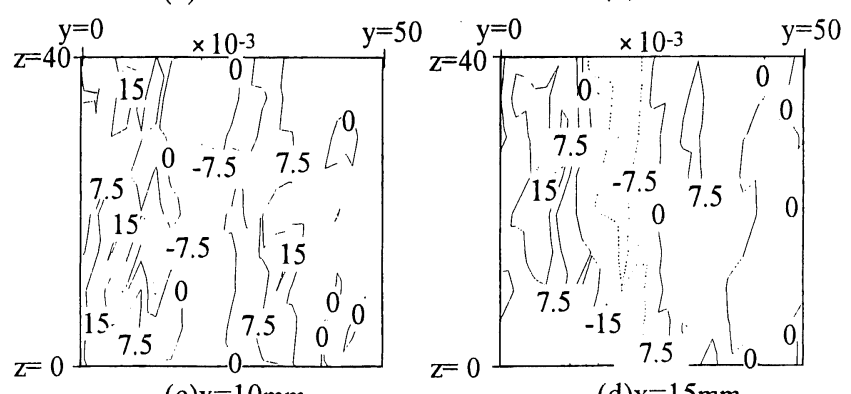

(d) $x=15 \mathrm{~mm}$

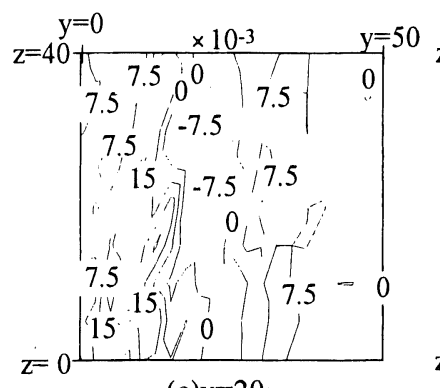

(e) $x=20 \mathrm{~mm}$

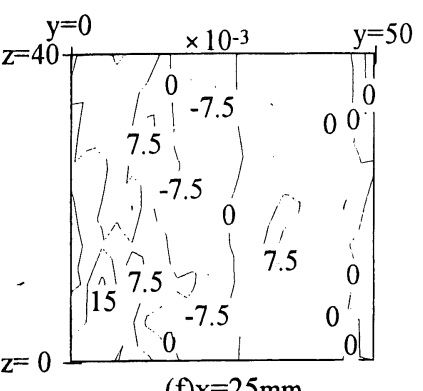

(f) $\mathrm{x}=25 \mathrm{~mm}$
Fig.4 Iso-Reynolds stress distributions on vertical section of third row at louver fins for Type B- 3 and $\mathrm{Re}=1,600$ 
バーの位置と次の列のフィン位置が関係し, 流れの変化 が小さいためによるものと考えられる.ルーバー角度が $15^{\circ}$ の場合には, Re 数によってスペクトルが異なり, ある周波数に対して大きなスペクトルの值を示す場合 や種々の周波数に対するスペクトルの值が大きくなっ たノイズを多く含んだ形のパワースペクトルも見られ た.

一方, フィンピッチが大きくなった Type B の場合の 結果については, ルーバ一角度が $10^{\circ}$ の場合には, 顕 著な周期性のある振動が見られない流れになっている と思われる. しかしながら， $15^{\circ}$ 及び $20^{\circ}$ のルーバー 角度では, 比較的鮮明な卓越周波数があらわれるパワー スペクトルが得られた.いずれのスペクトルにおいても $0.1 \mathrm{~Hz}$ 前後付近に卓越周波数が現れ, 周期の長い振動を 示す流れとなっていることが想像できる.

次に, ルーバー角度が $15^{\circ}$ の Type A-2 及び $15^{\circ}$ と $20^{\circ}$ の Type B-2 と B-3に対して, Re 数を変化させた場 合の $\mathrm{v}$ 方向成分に関するパワースペクトルにおける卓

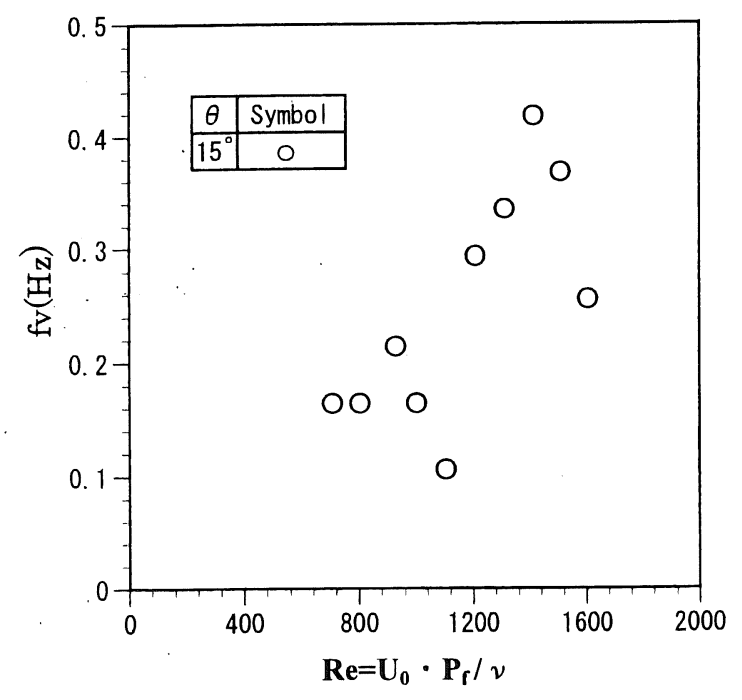

(a)Type A-2

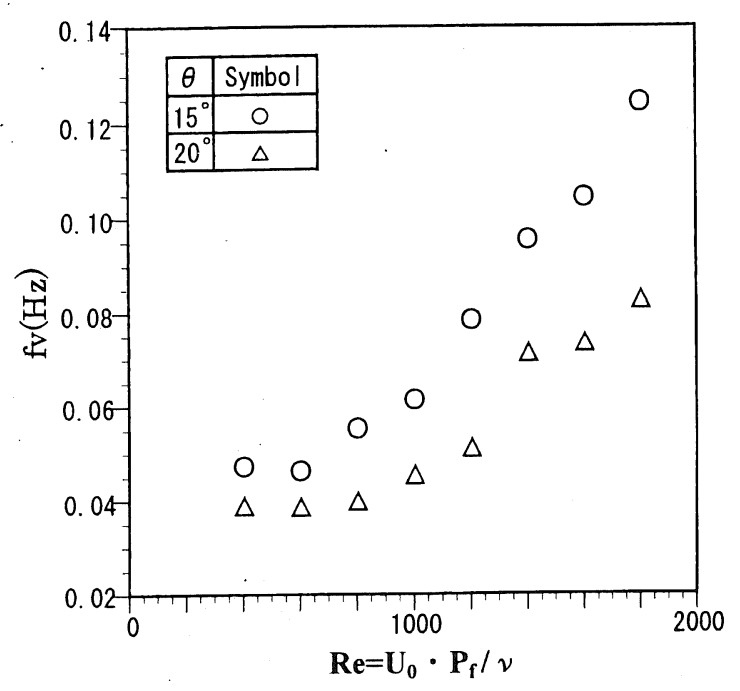

(b)Type B-2 and B-3
越周波数 $\mathrm{fv}$ を求めた，それぞれの結果を図一-5(a) と (b)に示す.

図ー5 (a)に示す Type A-2 の結果では, 確かにRe 数の 増加に対して f v は増大傾向にあるが, Re 数が 1,000 前後及び 1,500 前後では $\mathrm{f} v$ の值が大きく変化している. 前述のように,この場合鮮明な卓越周波数は得られてい ないので, 最大のパワースペクトルの值に対する $\mathrm{f} \mathrm{v}$ を プロットしているためによるものと思われる.それに対 して，(b)に示す Type B については，ルーバー角度が $15^{\circ}$ 及び $20^{\circ}$ の場合はともに, Re 数の増加に対して 1,000 前後までは $\mathrm{f} \mathrm{v}$ の変化は小さいが，それより大き くなると急激に増大している. $15^{\circ}$ と $20^{\circ}$ のルーバー 角度の違いで比較すると, $15^{\circ}$ の場合の方が $\mathrm{f} \mathrm{v}$ の值も 大きく，増加率も高くなっている.

以上のようなルーバーフィンまわりの流速変動の振 動特性と前述の乱れや流脈の可視化結果を含めて考察 をまとめると, 今回のようなルーバー角度の変化に対し ては, $15^{\circ}$ 以上のルーバー角度での流れにはルーバーフ イン入口付近で発生した縦渦がルーバー区間で増大し, 下流側に進むにつれて大きな振動を伴った流動に発展 しているものと思われる. 特に, $20^{\circ}$ のルーバー角度の Re 数が低いときには, 全体的に乱れが広がっているが, Re 数が大きくなると乱れは局部的に大きくなり，それ らの周辺での流れの回転流動が顕著に現れていると思 われる。

\section{4. 結論}

フィンピッチ及びルーバー角度を変化させてルーバ ーフィンまわりの流れの可視化を行った結果, 次のよう な結果を得ることができた.

(1) フィンピッチが狭い場合には, ルーバーフィンま わりの流脈の変化が小さく,ルーバー角度による流れの 変化も小さい. しかしながらフィンピッチが大きく, ル 一バー角度も大きくなると,ルーバーフィンまわりの流 脈の変化がはっきりとあらわれ, 縦渦を可視化すること ができた。

(2) L D Vによってもルーバーフィンまわりに発生す る渦の位置を明らかにするとともに, フィン入口による 流れの剥離, ルーバーフィンの屈曲部及びルーバーとフ インの配置がそれらの渦の発生と発達に関係している ことを明らかにすることができた。

(3)フィンピッチが大きく，ルーバー角度も大きい場 合には, 流速変動にはっきりとした振動が現れることが 明らかとなった。 またその振動周期は長く, 大きな縦渦 を伴う流動であることが明らかになった。

\section{<参考文献 $>$}

1) 梅田眞三郎, 他 3 名: ルーバーフィンまわりの流れの可視 化, 可視化情報, Vol.20, Suppl. No. 2, pp. 81-84, 2000

Fig.5 Relationship between $f_{v}$ and $R e$ in louver fins 